\title{
Corrigendum
}

\section{Impact of folic acid fortification of flour on neural tube defects: a systematic review - Corrigendum}

\author{
Cecilia Castillo-Lancellotti, Josep A Tur and Ricardo Uauy
}

First published online 22 February 2013

doi:10.1017/S1368980012003576, published online by Cambridge University Press 31 July 2012

The authors have corrected Table 2 to note that estimates from the study by Boulet et al. (ref 40) are between two postfortification periods, not between pre- and post-fortification

Table 2 Description of the studies assessing the impact of flour fortification with folic acid on the prevalence of NTD

\begin{tabular}{|c|c|c|c|c|c|c|c|c|c|c|c|c|}
\hline \multirow{2}{*}{$\begin{array}{l}\text { First author, year of } \\
\text { publication, } \\
\text { reference }\end{array}$} & \multirow[b]{2}{*}{ Country } & \multirow[b]{2}{*}{ Period } & \multicolumn{3}{|c|}{ Spina bifida* } & \multicolumn{3}{|c|}{ Anencephaly* } & \multicolumn{3}{|c|}{ NTD $^{*}$} & \multirow[b]{2}{*}{ Source of data } \\
\hline & & & PreF & PostF & $\%$ & PreF & PostF & $\%$ & PreF & PostF & $\%$ & \\
\hline Boulet, $2008^{(40)}+$ & USA & $\begin{array}{l}1999-2000 / \\
2003-2004\end{array}$ & $3 \cdot 51$ & $3 \cdot 39$ & $3 \cdot 4$ & $2 \cdot 47$ & $1 \cdot 98$ & $19 \cdot 8$ & & & & $\begin{array}{l}\text { Birth certificates and } \\
\text { prenatal data of live } \\
\text { births and stillbirths } \\
\text { from twenty-one } \\
\text { birth defects } \\
\text { surveillance } \\
\text { systems }\end{array}$ \\
\hline
\end{tabular}

†Estimates from the study by Boulet et al. are between two post-fortification periods, not between pre- and post-fortification.

\section{Reference}

Castillo-Lancellotti C, Tur JA, Uauy R (2012) Impact of folic acid fortification of flour on neural tube defects: a systematic review Public Health Nutrition published online 31 July 2012, doi:10.1017/S1368980012003576 